\title{
Nazi Race Theory and Belief in an "Aryan Race": A Profound Failure of Interdisciplinary Communication
}

\author{
Christopher Mark Hutton, The University of Hong Kong, Hong Kong \\ SAR, China
}

\begin{abstract}
In the popular and scientific imagination, Nazi science, in particular theories of race, loom large as a point of reference for discussion of moral issues within science. This paper argues that popular and academic discussion of Nazi race theory has been in general highly misleading, and vitiated by a failure to differentiate between: (1) popular, propagandistic and aesthetic stereotypes of race; (2) racial policies; (3) academic race theory as expounded within scholarly publications in the Third Reich. Since these have not been clearly distinguished, discussion of the relationships between them has of necessity been confused. The case of the "Aryan race" is clear evidence of this confusion, since academic race theorists consistently rejected the notion as unscientific, as did policy makers after 1935. This widespread preconception that Nazism promoted the idea of an Aryan race is based on the popular use of the "Arisch" in the public culture of Nazi Germany. Textbooks on race published in Nazi Germany however routinely rejected the use of "Aryan" as a racial term, pointing out that it derived from the discipline of linguistics. There has been an almost complete lack of communication between scientists, historians and linguists over these key questions, and this has produced a profoundly entrenched set of misunderstandings over such as issues as the relationship between Darwinism and Nazism, ideas about racial purity, hybridity, racial determinism and the ideological contribution of linguistics to Nazism. These misunderstandings echo through wider debates about the politics of science, to the detriment of public debate about the nature of human identity and human diversity.
\end{abstract}

Keywords: Race, Nazism, Aryan, Darwinism, Politics of Science

$\mathrm{I}$

N THE POPULAR and scholarly imagination, Nazi scholarship, in particular theories of race, looms large as a point of reference for discussion of moral issues within science. Nazism is frequently associated with pseudo-science, but has also been seen as representing the pathologies of all normative science and technology. Nazism and race theory have been associated with the so-called "Enlightenment project", but profound hostility to the Enlightenment was a feature of European fascist thought and of key strands of Nazi ideology. Nazi ideologues associated the Enlightenment with a "Jewish" universalism and an urbanized modernity which was rapidly erasing racial and cultural difference. Nazi science is constituted as a pseudo-scientific "other", against which normative science and scholarship can be measured. Yet one of the problems with situating Nazi scholarship and science within the Western tradition is that one can find there almost any philosophical and intellectual position, with the important exception of a political and moral commitment to human equality and dignity.

Popular and popular-academic discussion of Nazi race theory has been in general highly misleading, and vitiated by a failure to differentiate between (i) popular, propagandistic and aesthetic stereotypes of race; (ii) racial policies; (iii) academic race theory as expounded

The International Journal of Science in Society

Volume 1, Number 4, 2010, http://science-society.com/journal/, ISSN 1836-6236

(C) Common Ground, Christopher Mark Hutton, All Rights Reserved, Permissions:

cg-support@commongroundpublishing.com 
within scholarly publications in the Third Reich. There has been an almost complete lack of communication between scientists, historians and linguists over these key questions, and this has produced a profoundly entrenched set of misunderstandings. These misunderstandings echo through wider debates about the politics of science, to the detriment of public discussion of a range of issues concerning human identity and human diversity. In this paper I wish to illustrate this with reference to the idea of an "Aryan race", as this offers a relatively clear starting-point for a discussion of the place of Nazi science within the history and politics of science (for a full discussion, see Hutton 2005).

Within Nazi scholarship there are three fundamental frameworks at work in the study of human identity and diversity. The first involves the popular, political and academic concept of "people" or Volk, with its roots in the Biblical idea of a people as a lineage group sharing a territory, language and culture. The terms "Aryan" (arisch) and "German" (deutsch) both belong to this paradigm: the relevant academic disciplines are linguistics and folklore studies. The second is that of "race" (Rasse). This is also a popular, political and academic concept, which has its origin in late eighteenth and early nineteenth century attempts to systematize, classify and explain human physical variation. The relevant academic discipline is "racial anthropology" (Anthropologie, Rassenkunde). The third framework recognizes reproductive communities or groups, from the smallest ("family") to the largest, "population" (Bevölkerung, Vitalrasse). This framework looks at populations as biological collectives with particular patterns of inherited genetic characteristics, as in the statistical discipline of population genetics. The relevant academic disciplines are evolutionary biology and genetics. The corresponding applied discipline is eugenics (Eugenik, Rassenhygiene, Rassenpflege, Fortpflangzungshygiene).

While these distinctions were by no means absolute, and raised a whole host of scientific and ideological issues, they were a common reference point for debate. For example, it was widely recognized as a basic and uncontentious fact about human identity that linguistic identity ("mother tongue") and racial identity were distinct and should not be confused (Hutton 1999). To take the most important case: just because many Jews spoke German as native speakers did not, in the eyes of racial theorists, detract in any way from their essential racial "otherness". To fail to distinguish between these two forms of identity in the academic climate of the 1920s and 30s was to commit an elementary intellectual error. The presupposition that Nazi race theorists believed in the existence of an Aryan race does indeed impute to them such an error, since the term "Aryan" was derived from the academic study of language. Yet Nazi race theorists, along with their international colleagues, rejected the notion of an Aryan race as unscientific. It is important to be clear about this, because this presupposition about belief in an "Aryan race" in turn supports a comforting and highly distorted caricature of Nazi academia. Nazi scholarship and scientific research is frequently presented as wholly given over to pseudo-science, fantasies of a superior "master race", and mystic Germanophilia. The reality is a lot more complex and more disturbing, and specialist writings, mainly in German, which show that complexity have not been received into the mainstream of historical and popular discussion (e.g. Weingart et al.1992, Weingart 1995, Weikart 2004).

The failure to recognize these distinct paradigms has been compounded by problems in the translation of key terms. The term widely used in English, "Aryan race", now almost synonymous with Nazi thought, has no unambiguous counterpart in the German language. This can be explained by the fact that the term "Aryan" belongs in general to the discourses of Volk, i.e. the first framework defined above. The normative German term is therefore 
arisches Volk, not arische Rasse. While one can find exemplars of arische Rasse in various historical contexts, no academically trained race theorist in the 1920s and 30s would have used the term. This was equally true after the National Socialist seizure of power in 1933. The widespread preconception that Nazism promoted the idea of an Aryan race is based on the popular use of the arisch in the public culture of Nazi Germany, including its use as an identifier of race as in the pairing of "Aryan" and "Semite". Textbooks on race published in Nazi Germany, however, routinely rejected the use of Aryan as a racial term, pointing out that it derived from the discipline of linguistics. Academic race theorists and linguists were concerned about popular understandings of "Aryan" as a racial term, and the confusion engendered by official use of arisch and Arier in the early days of the regime. In deference to their views, policy makers abandoned use of the term in official contexts after 1935. To speak of an Aryan race was a complete nonsense for Nazi race theorists, and thus any notion of the "purity" of the Aryan race would likewise have been completely meaningless.

Thus when writers in English talk of Nazi belief in an "Aryan race", it is quite unclear what the German equivalent of this term is meant to be. The phrase in English automatically creates confusion between two quite separate disciplines involved in the study of human identity. A further fundamental translation issue arises with the term Rassenhygiene, often rendered as "race hygiene". This translation suggests that Rassenhygiene refers primarily to anthropological race, but in fact its primary meaning is "race" understood in the sense of "population". A less misleading translation for this term is "eugenics". There was a complex debate about how eugenic fitness related to anthropological race (and racial mixing), but this secondary debate assumed the existence of two separate intellectual frameworks. To assume that "race hygiene" was a branch of racial anthropology is to confuse two distinct (albeit interacting) discourses. If we use the terms "Aryan race" and "race hygiene" in discussions of Nazi science, we are ignoring boundaries which were the very stuff of intellectual debate and controversy, both in Nazi Germany and internationally.

This problem of terminology is compounded by an insistence on treating Nazi thought as a static system. Developments after 1933 were highly complex, but there is a clearly discernible movement from relative intellectual diversity to an increasingly focused technocratic and applied science model. Many disciplines sought to promote a holistic vision of total, ideologically engaged thought, in which the barriers between science and humanities, and between intellectual life and the political and social worlds, would be broken down. There were attacks on the elitism and remoteness of traditional academic German culture. By the late 1930s these "Aryan" or "Germanocentric" initiatives had floundered, including attempts to promote a holistic-intuitive Goethean science, in the context of hostility to Western rationalism and Darwinism. The promotion of "Aryan physics" and völkisch (Germanocentric) mathematics was marginalized from 1936 onwards (Segal 2003). The division between humanities and science was reasserted, in line with accepted international standards, and the regime took a technocratic turn, strongly favoring applied science (Sieg 2001: 258). Nazism actually moved closer towards international norms in science as the regime became more radical (indeed genocidal) in its policies.

The interaction between ideas of people or Volk, race, and genetic inheritance was both intellectually complex and politically sensitive. From the point of view of racial anthropology, the racial identity of the German Volk was hybrid or mixed (even leaving aside the Jewish and African elements). The dominant model was elaborated by H. F. K. Günther's (18911968). It diagnosed combinations of the following elements in the German Volk: Nordic 
(nordisch); Mediterranean (westisch, mediterran, mitelländisch); Dinaric (dinarisch); Alpine (ostisch, alpin); East Baltic (ostbaltisch); Phalian (fälisch, dalisch). According to racial anthropologists, just as there was no "German race", there was also no "Jewish race". Günther analyzed Sephardic Jews as combinations of Oriental (orientalisch); Near Eastern (vorderasiatisch); Hamitic (hamitisch); Nordic (nordisch); Negro (negerisch). Ashkenazic Jews were made up of the following races: Near Eastern (vorderasiatisc); Oriental (orientalisch); East Baltic (ostbaltisch); Mongolian (mongolisch); Nordic (nordisch); Hamitic (hamitisch). The Near Eastern race was related to the Dinaric race, in that both were off-shoots of a common ancestral race (Stammrasse). The implication was that at the level of race there was an overlap between Germans and Jews (see Günther 1933, 1934, Hutton 2005: 35-63). The framework promoted by racial anthropology highlighted the fuzzy racial identity of the German Volk and the uncertainty of its boundaries. Further, after 1933 the idealization of the Nordic race became politically problematic, as many Germans feared that Nazism was a form of Nordic colonialism, and that non-Nordics would be treated as second-class citizens, above only the Africans, Jews, and Slavs.

Orthodox racial anthropology on one level offered at best ambivalent support for the unity of the German Volk, and could be read as suggesting that the primary links were across different peoples rather than within them. Nordic ideology, an off-shoot of racial anthropology, was a form of elite racist internationalism, and hostile to European nationalism. The European nation states were viewed by Nordicists as constructs of language and territorial politics. There were Nordic elements in the populations of many countries, including obviously the Scandinavian nations, Britain and the United States, but also among the Slavs. Racial anthropology in its Nordicist guise was therefore politically problematic, since it presented the concept of Volk as a secondary grouping, and suggested a potential bond between the elites of a wide variety of politically antagonistic nations (Holler 1934).

There is no doubt that any racial anthropologist or other scholar promoting the notion of an "Aryan race" in Nazi Germany would have been instantly dismissed. While there was no such incident, the case of Karl Saller (1902-1969) is worth a brief mention here. Following his advocacy of the existence of a "German race" (deutsche Rasse), Saller's entitlement to hold university lectures was withdrawn in January 1935. His book, Vineta, co-authored with Friedrich Merkenschlager (1892-1968), was banned by the Prussian state (Merkenschlager and Saller 1935). Saller's basic position was that races were fluid, historically dynamic and constantly interacting and changing. While the distinction was important, there was no absolute boundary between Volk and Rasse, so that a Volk community could become a racial community ("Volksgemeinschaft kann Rassengemeinschaft sein", Saller 1930: 215). While Saller was a patriotic German and a supporter of the National Socialist revolution, this apparent mixing of Volk and Rasse was academic heresy, as was Saller's celebration of Germany as a dynamic racial crossroads between East and West. Saller had also attacked Günther and was hostile to what he viewed as the over-emphasis on the Nordic race found in German racial anthropology (see Lüddecke 1995, Hutton 2005: 149-154).

A further complex set of problems arose from the interaction between race and genetics. The genetic revolution, and the application of a Mendelian model of heredity to the transmission of racial features, had been applied to the study of human race (Fischer 1913). The conclusion was that race was not an indivisible attribute, and different aspects of racial identity could be inherited separately. Race was in effect a construct, in that no single member of the contemporary German (or any other) Volk was racially pure. There were racial 
traits, but no races operating as autonomous communities. To put the matter at its simplest, the logical conclusion from this model was that there was no necessary link between a Nordic appearance and a Nordic mentality or soul. The "phenotype" (Erscheinungsbild, Phänotypus) was essentially distinct from "genotype" (Erbbild, Genotypus): the measurement of the appearance and physical form of an individual did not give the observer access to essential hereditary make-up. Evolutionary biologists and geneticists argued that there was no way to purify the German Volk by selective breeding. A superficial Nordification would not necessarily mean that Nordic character traits were also present (Baur 1936), since one could be Nordic in appearance yet be psychologically Jewish. But if there was no link between physical appearance and inner character or nature, what was the role of racial anthropology and racial measurement? Racial anthropologists were necessary to enforce the classifications of the state, but they could not sustain a leading ideological or policy role because their intellectual tools had been shown to be inadequate.

The idea of the unity of the German Volk was fundamental to Nazi political rhetoric, and racial anthropology, as the contender to be the master discipline within Nazism, was disruptive politically, and intellectually vulnerable to the neo-Darwinian orthodoxy that increasingly dominated. The idea that the German Volk was somehow determined in its nature by the Nordic race soul would have been laughable to the geneticists who were being promoted within the SS from 1937 onwards (Heberer 1943). By the late 1930s the regime was marginalizing racial science in favour of neo-Darwinian evolutionary genetics. Neo-Lamarkianism was officially unwelcome (though there was some public debate) as it was associated with Soviet science and environmental determinism. The idea of racial anthropology as offering a unified framework for the humanities and science was in part discredited and superseded by a division between the discourses of Volk as a unique cultural and historical agent and population genetics, with its emphasis on the genetic health or individuals and family groups.

The marginalization of racial anthropology involved a shift in the underlying intellectual deep structure, and reflected the central role that the concept of Volk played within all levels of political and academic discourse. The Volk was the site of linguistic and cultural difference; genetics offered a diagnostic for the heredity health of the Volk. Psychology rather than racial anthropology had the potential to provide a framework for discussing issues of heredity versus environment. However overall, racial anthropology played two crucial roles. It identified Jews and Africans and others as racially foreign, and this gave intellectual authority to the political actions which sought to purify the Volk. Secondly, it played an instrumental role in producing certificates of racial identity and carrying out other acts of racial classification. Racial anthropology ultimately provided intellectual justification for policies such as forced sterilization, loss of civic rights and genocide, even if genocidal rhetoric was not a feature of published academic race theory.

Any understanding of Nazi race theory as "pseudo-scientific" fails to do justice to the historical phenomenon. In Nazi Germany discussions of race made constant reference to the criterion of "scientific standards". But this concept had its own institutional and intellectual politics, as can be seen in the attack by the Nazi party expert on race, Walter Gross (19041945), on the "intuition-based" race psychology of Ludwig Clauss (1892-1974) (Weingart 1995, Hutton 2005: 181-186); the dismissal by Gerhard Heberer (1901-1973) of ideological attacks on evolutionary theory and Darwinism (Heberer 1943: iii-iv), and in discussions of Lamarckianism (Böker 1934, Holler 1934, Plate 1934, Hutton 2005: 190-194). 
Given the importance that Nazism and Nazi science plays in discussions of the ethics, and history of science, it is unfortunate that so much misinformation is circulating in the public sphere. Standards histories of the Nazi era generally make little or no reference to debates about the nature of race, and the lurid associations of the word "Aryan" obscure the fact that mainstream Nazi scholarship was not radically at odds with the wider framework adopted by European intellectuals. Contemporary debates in India about labels such as "Aryan" and Dravidian" use both British colonial scholarship and Nazism as important points of reference, but often without directly confronting the actual formulations and ideas involved. Translations of the key terms into English fail to reflect the important intellectual boundaries drawn by Nazi scholarship, and the confusions attributed to Nazi scholarship (e.g. between linguistic and racial identity) are actually found in the critiques themselves. The idea of race as a construct is often juxtaposed to Nazi essentialism, without any awareness of the complex way in which race theorists such as Eugen Fischer recognized that race was indeed a construct. The Nazi understanding of race needs to be set within an evolving intellectual and political landscape, rather than singled out as a single, static and defining idea.

It is not the task of the history and philosophy of science to offer reassurances that we have overcome the mistakes of the past. It is rather through a close reading of the texts themselves, and of the multileveled texture of the socio-political and policy context in which those texts were produced, that we engage with the true complexity of the present.

\section{Acknowledgement}

This paper was supported by RGC-GRF grant HKU 744708H.

\section{References}

Baur, Erwin (1936). Menschliche Erblehre. In: Erwin Baur, Eugen Fischer and Fritz Lenz, eds. Menschliche Erblehre. Menschliche Erblehre und Rassenhygiene, vol. 1. München: J. F. Lehmann, pp. 3-94.

Böker, Hans (1934). Rassenkonstanz - Artenwandel. Rasse: Monatsschrift der Nordischen Bewegung 1: $250-1$.

Fischer, Eugen (1913). Die Rehobother Bastards und das Bastardisierungsproblem beim Menschen. Jena: Gustav Fischer.

Günther, Hans (1933). Kleine Rassenkunde des deutschen Volkes. München: J. F. Lehmann.

Günther, Hans F. K. (1934). Rassenkunde des deutschen Volkes. München: J. F. Lehmann. First published, 1922. Subsequent editions, 1926, 1930.

Heberer, Gerhard, ed. (1943). Die Evolution der Organismen: Ergebnisse und Probleme der Abstammungslehre. Jena: Gustav Fischer.

Holler, Kurt (1934). Übersicht über die Nordische Bewegung im letzten Jahre. Rasse: Monatsschrift der Nordischen Bewegung 2: 31-2.

Hutton, Christopher (1999). Linguistics and the Third Reich: race, mother tongue fascism and the science of language. London: Routledge.

Hutton, Christopher (2005). Race and the Third Reich: linguistics, racial anthropology and genetics in the dialectic of Volk. Cambridge: Polity.

Lüddecke, Andreas (1995). Der 'Fall Saller' und die Rassenhygiene: Eine Göttinger Fallstudie zu denWidersprüchen sozialbiologistischer Ideoligiebildung. Marburg: Tectum Verlag.

Merkenschlager, Friedrich and Karl Saller (1935). Vineta. Eine deutsche Biologie von Osten her geschrieben. Breslau: W. G. Korn. 
Plate, Ludwig (1934). Umweltlehre und Nationalsozialismus. Rasse: Monatsschrift der Nordischen Bewegung 1: 279-83.

Saller, Karl (1930). Leitfaden der Anthropologie. Berlin: Julius Springer.

Segal, Sanford L. (2003). Mathematicians under the Nazis. Princeton: Princeton University Press.

Sieg, Ulrich (2001). Strukturwandel der Wissenschaft im NS. Berichte zur Wissenschaftsgeschichte 24: $255-270$.

Weikart, Richard (2004). From Darwin to Hitler: evolutionary ethics, eugenics, and racism in Germany. New York: Palgrave Macmillan

Weingart, Peter, Jürgen Kroll and Kurt Bayertz (1992). Rasse, Blut und Gene: Geschichte der Eugenik und Rassenhygiene in Deutschland. Frankfurt/M.: Suhrkamp.

Weingart, Peter (1995). Doppel-Leben: Ludwig Ferdinand Clauss zwischen Rassenforschung und Widerstand. Frankfurt/M. and New York: Campus.

\section{About the Author}

\section{Prof. Christopher Mark Hutton}

Christopher Hutton is professor in the School of English at the University of Hong Kong. He holds a BA in Modern languages (1980) and a DPhil in General Linguistics from the University of Oxford (1988), an MA in Linguistics and Yiddish Studies from Columbia University, New York (1985), and an LLB (Manchester Metropolitan University, 2008). He held a research position at the Oxford Centre for Postgraduate Hebrew Studies from 19781989, and was Assistant Professor in the Department of Germanic Languages at the University of Texas at Austin from 1987-1989. His research is concerned with the politics of language and linguistics, the history of Western linguistics in its relationship with race theory, and within the context of European scholarship in Asia. His publications include Linguistics and the Third Reich (Routledge, 1999), Race and the Third Reich (Polity Press, 2005), Language, Law and Definition (with R. Harris, Continuum, 2007), Language, Meaning and the Law (Edinburgh, 2009). 
Copyright of International Journal of Science in Society is the property of Common Ground Publishing and its content may not be copied or emailed to multiple sites or posted to a listserv without the copyright holder's express written permission. However, users may print, download, or email articles for individual use. 